\title{
ELECTRONIC GOVERNMENT RUKUN TETANGGA MODEL
}

\author{
Darius Antoni, Muhamad Akbar, Fatoni
}

Fakultas Ilmu Komputer, University of Bina Darma

Jalan Jenderal Ahmad Yani No.3, Palembang, 30264, Indonesia

E-mail: darius.antoni@binadarma.ac.id,muhamad.akbar@binadarma.ac.id,fatoni@binadarma.ac.id

\begin{abstract}
E-government is the one of facilities of government to interact and communicate with the citizen as the government's ability to improve service performance. However, not all citizen, including the poor, can benefit the e-government services. To answer the issue, this research developed e-government model of Rukun Tetangga (RT) based on eight factors consisting of content providers, direct-to-consumer, valuenet-integrations, full-service providers, infrastructure service providers, market, collaboration and virtual communities. Quantitative research was used to collect data through interview with 24 participants including head of RT, citizen and Employees District Office in Palembang. The findings of this study showed that an e-government RT model was required to help Palembang Government to meet needs of the citizen, which had impacts to improve services to entire levels of society.
\end{abstract}

Keywords: Rukun Tetangga, e-government, services, poor

\section{Introduction}

Nowadays, the concept and definition of electronic government (e-government) has been widely expressed by experts including government practitioner's entire the world. The World Bank defines e-government as a tool used by governments through information technology such as Wide Area Networks, Internet and mobile computing that have the ability to connect communities, businesses and government institutions $[1,2]$. The United Nations Development Program defines e-government as an application of information and communication technology. In Indonesia, e-government is developed in 2003 under Presidential Instruction No. 3/2003 on National Policy and Development Strategies whereby e-government is a government effort to improve efficiency, effectiveness, transparency and accountability of governmental administration based on information and communication technology [3]. With the egovernment, it is expected that the work process in the government environment can be more optimal with the use of information technology so as to improve service performance to the citizen.

The success of e-government is not only influenced by in a policy and strategy, but also the readiness of the infrastructure and the readiness of the users. It is because no matter how well a program will succeed if it is not accompanied by the readiness of the infrastructure and users themselves. Heeks and Bailur [4] state that 40 governments in developing and transition countries found that $35 \%$ of e-government implementations could be categorized as total failure, while $50 \%$ of governments half failed to implement e-government. In fact, of the many developing countries, only $15 \%$ of successful governments run it. The failure of e-government development in Indonesia due to lack of infrastructure, weak leadership and culture of citizen [5]. The infrastructure includes digital inequality, lack of infrastructure supports and lack of system services. The availability of technologies such as infrastructure problems is often still a constraint in developing countries. Implementation of e-government programs requires extensive computer network technology, sufficient computer equipment within government institutions and reliable supporting infrastructure that is evenly distributed throughout the region. However, we need to admit that, infrastructure is not one factor in success in the implementation of e-government in a country.

Several research on e-government has been widely implemented where more emphasize on developing government-to-government, government-to-citizen, government-to-business, government-to-civil society and citizen-to-citizen as media communication, coordination, and improvement of service standardization to the community. Moreover, the research on egovernment model development is also emphasized in e-government typology oriented to administration, provision of information and users who only analyze the content, design and services 
of municipal, local and central government websites in Indonesia [3, 6, 7].

Beside the previous studies above, a lot of the development of e-government in the local government are focused on the development of egovernment level internal Local Government Work Unit or Organisasi Perangkat Daerah (OPD) namely applications or information systems used for internal OPD namely Regional Management Information System, Regional Development Control Information System, Employee Attendance System and official website.

Despite much research and development of e-government in the Indonesian, a research is needed to develop a model e-government that can interact and communicate throughout the community and citizen. The one of influenced factor is because there are numerous people difficulty in accessing e-government that exists today. This is because the people, especially the poor people, does not have the ability to purchase the equipment used to access e-governance such as smartphones, laptops, computers and internet access [1]. Thus, in interacting and communicating with local government, the poor tends to have different cultures and approaches [2]. For example, the trend of the poor people of Palembang shows that almost all of them uses the government services through the head of the neighbourhood association or ketua Rukun Tetangga (RT) to interact with local government such as local subdistrict and local district office. This is because the $\mathrm{RT}$ head recognizes the process in government and is trusted by the people to assist them in interacting with the local government. In addition, from the local government perspective including subdistrict and district office also require the role of the RT head in dealing with the community information. This is evidenced by requests for data or information from these local government offices from RT heads, such as data from poor people, regional data and others. Thus, it can be concluded that the head of the RT has a very significant role as the mediator between the people and the government.

Based on previous research and phenomena occurring in the community, this research would like to identify the role of RT chairman in the government to develop e-government entitled "EGovernment Rukun Tetangga Model”.

\section{Development of Electronic Government Model Rukun Tetangga}

Rukun Tetangga (RT) is the lowest administrative division of Indonesia. It is chaired by RT head that elected by its citizen. A RT consists of a number of households. Therefore, the existence of Rukun Tetangga is expected to play an important role in improving the welfare of the community and able to increase community participation in achieving welfare itself, both in terms of development and others and help the task of service to the community that is the responsibility of government.

Based on the Regional Regulation of Palembang City No. 3 of 2017 on the Amendment of Regional Regulation No. 8 of 2007 on the Establishment of Rukun Tetangga (RT) that as chairman of the RT has the main duties namely, (1). Assist in carrying out the duties of service to the community which is the responsibility of the Government, (2). Maintaining security, fulfilment and harmony of life of citizens, (3). Arranging plans and implement development by developing aspirations and self-help people, (4). Reporting the development of territorial and population potential.

Duty of the RT head by Palembang City Regulation No. 8 of 2007 on the Establishment of RT has the following functions: (1). Coordinating among people, (2). Implementating and bridging the relationship between community members and government, (3). Handling citizens' social issues through the steps and activities agreed upon in the deliberations according to the conditions and needs of the people.

Based on the explanation above, this research will attempt to build or develop the e-government model of RT to assist the government of Palembang in applying all levels of community. EGovernment Rukun Tetangga Model is developed based on the e-government model developed by Janssen, et al. [8] as the basis for collecting data and information from RT heads in Palembang then as to develop the concept of e-government RT by using and modifying the business model consists of 8 business models are: 1. Content provider; 2 . Direct-to-consumer; 3. Value-net-integrations; 4. Full-service provider; 5. Infrastructure service provider; 6. Market; 7. Collaboration; and 8. Virtual communities.

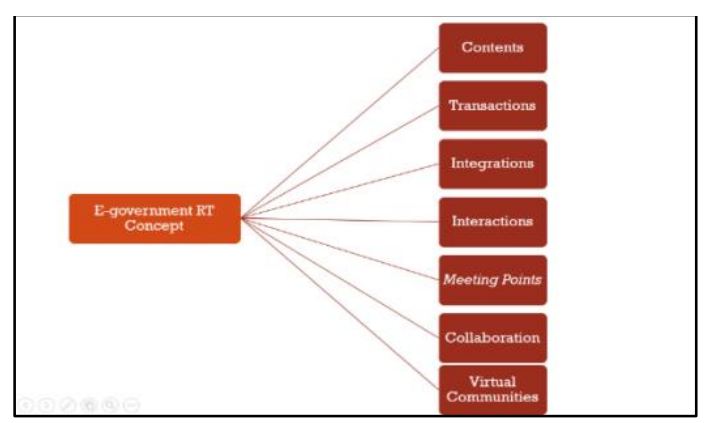

Figure 1. E-Government Model Developed By Janssen, et al. [8] 
Content e-government is the provision of static and dynamic content including product and news information. This content comes from one organization and can be customized to fit customer needs. Often this is an internal organization or centric, not a customer-oriented and first (and sometimes latter) endeavour to have an online presence. Content provider it has the characteristics to provide information about their own organizations, products, and services that focus on the organization's core goals. It also has functions like menu structure, search options, hyperlinks to related sites, news, and sometimes the use of profiles and subscription options. Kurniawan, et al. [9] reveal that information is very important in the city and district government websites in Indonesia to be able to interact with the community. To maximize the information available on the official website of government required a hyperlink to all existing social media [10]

Net value integrators are described as models for coordinating the collection, processing, and distribution of information from multiple organizations, agencies or units in government. This is a type of business model that is connected to one another that focuses on specific customer satisfaction. In contrast to other models that provide full services, net-value-integrators have the function to coordinate the provision of services from other organizations and do not provide services directly. This model has the characteristics of forming interconnection and collaboration between organizations in the network to provide one-stop shop to the community. Each organization maintains its own identity and service request directed to the responsible organization, which takes care of the settlement. Typical functions: subscription, alerting, events, integrated form to request service products from various organizations. In a study conducted by Layne and Lee [11] reveal that the government has various tasks and responsibilities as well as various units of work with different tasks if connected together, it can see directly the existence of interconnected systems within the government that is integrated information based. Therefore, people will easily transact from one point of government service and complete all transaction affairs provided and with self-services in various divisions with the concept of "one-stop shopping".

The concept of direct-to-citizen service involves provision of direct services to customers and businesses including custom made pages and subscription options. This goes beyond the content provider model because not only information is available, but also transactional functionality is provided. This concept focuses on the traditional functions, services, and products of the organization. Sometimes some new services are enabled that Internet providers, such as tracking and search, online agenda, and functionality to create meetings. This concept has an awareness that is focused on creating transactions and sales services provided by the organization itself. Users help themselves by focusing on self-service options. The types of services include service catalogues, self-services, meetings, tracking, and financial settlement. Meanwhile, Antoni, et al. [12] reveal that responsive e-government services can increase the number of people's participation in using them. One example is providing information needed by the community such as family cards through Kiosks. Zambrano [13] states that direct service to the community can be done by providing legal information and services such as online legal aid.

E-government market is a concept which unites supply and demand using the market mechanism. In terms of service providers and innovations, markets are created by intermediaries and partners. Intermediaries are often government organizations that benefit from matching demand and supply. It has characteristics as intermedia between suppliers and service providers. The concept is developed for finding supply and demand, showed the best match between supply and demand, recommend the offering or requesting, storing the information supplier and the seller personally. Janssen, et al. [8], state that there is need to matches supply and demand for volunteer vacancies. Organizations can advertise their jobs and people interested in doing volunteer work can browse and search jobs. In this way market friction is reduced, there are volunteers who are not volunteers and volunteers.

Full-service provider facilitates an interaction between the government and the citizen through direct information and service provision. This involves collaboration between organizations to provide a one-stop shop. Society is not directly served by agencies and organizational identity is often hidden and does not play a major role. Sinjeri et al. (2010) affirms that the use of official websites from government, agencies or certain agencies accessible to the public via the Internet requires a monthly fee for internet and fees for buying hardware and computer course fees to learn to use the website. Public kiosk provided by a combination of government agencies is a solution for the community to interact with local and central government. Kiosk is placed in areas that have a minimal IT infrastructure and in areas that have lower middle class or the poor people. In the service concept according to an IT view a citizen 
can contact a single point of government and complete every level of government transactions the concept of "one-stop shopping" [11]. To realize the e-government project, the main aspects to note are the government framework from the electronic side to the technological and social and organizational aspects (Tambouris 2001). The IT use can reduce corruption by promoting good governance, strengthening reform-oriented initiatives, reducing potential for corrupt behavior, enhancing relationships between government employees and citizens, enabling citizen tracking activities, and by monitoring and controlling employee government behaviour (Bertot, Jaeger \& Grimes 2010).

E-government collaboration concept is to facilitate the public to participate in submitting ideas, suggestions or criticism in the decision and policy making. The results of these decisions and alternative policies can be discussed and evaluated together. The concept of collaboration has a rational arena to enable electronic participation and discussion between communities, businesses and governments. The example is chat application and online discussions, whiteboards applications, evoting, sharing documents, wikis, and simulations to compare and evaluate alternative policies. Ebbers, Pieterson and Noordman (2008) suggests that it takes numerous of channels from information technology including website, mobile phone, chat application and online discussion to generate collaboration between government and society in making decisions and policies in improving public services performance. The European (2015) reveals that collaboration with communities can provide new insight into new issues and services to the government. In addition, opportunities provided by e-government for the community to dialogue with public authorities (to suggest, comment on and influence policy and policy agendas) can increase transparency and encourage greater participation in democratic public life.

The concept of virtual community is described as a model concerning the creation of a community or a group of repeat customers. It aims to provide content that attracts the public to return periodically to the government website. This virtual community has interesting topics and is able to retain its users, such as online discussion forums, blogs, information searches, actual content, and information provision. Janssen et al. [8] provide examples of Rotterdam drug information is a virtual community dealing with drug related issues. It provides documentation and information about drugs and the risk of illegal drugs. Drug consumers can chat with each other to share thoughts and people can ask all kinds of questions to internet users.

\section{Research Methods}

Methodology of this research is a qualitative [14]. It is used to obtain all the facts related to the development of e-government RT model. Therefore, this concept can help government and district of Palembang interact directly to all layers of society. The based on the research questions, the cases are required to include RT heads, communities and government staffs in Palembang as users and service providers to enable understanding of how they communicate and interact each other. There are three case studies conducted, to seeks to provide an understanding of the phenomenon and to generate ideas and theories [15] and member validation [16].

The interviews are exploratory in nature, consisting of open-end question to get views and opinions from community, head of RT and District Office staffs the city of Palembang associated with the development of RT e-government concept based on the theory developed by Janssen, et al. [8] in improving public servants in the city of Palembang. Interview results are used to obtain forms of e-government RT services that can be developed. Location of sub-districts and RTs selected are slum locations where there are many poor people live. The interview time takes 50-60 minutes and is stored in the form of interview transcripts sent to the participants for validation and clarification. Table 1 is a list of participants in this study.

The interviews were supplemented with evidence from documents and observations. Documents included those publicly available (e.g. government websites) and provided by participants (e.g. forms and procedures). The RT heads also provided the researchers with a guided tour of their social and culture in community for understanding the environment of community.

TABLE 1 LIST OF PARTICIPANTS

\begin{tabular}{llcc}
\hline No & Areas & Number & Participants \\
\hline 1. & Kelurahan & & RT 08 \\
& Silaberanti & 2 & $\begin{array}{c}\text { and RT } \\
11\end{array}$ \\
& & & RT 28 \\
2. & Kelurhan 1 & 2 & and RT \\
& Ulu & 20
\end{tabular}

3. Kelurahan $\quad 1 \quad$ RT 29 


\begin{tabular}{|c|c|c|c|}
\hline 4. & $\begin{array}{l}\text { Kelurahan } \\
16 \text { Ulu }\end{array}$ & 1 & RT 56 \\
\hline 5. & $\begin{array}{l}\text { Kelurahan } \\
15 \text { Ulu }\end{array}$ & 1 & RT 63 \\
\hline 6. & $\begin{array}{l}\text { Kelurahan } \\
\text { Plaju Ulu }\end{array}$ & 3 & $\begin{array}{l}\text { RT } 23, \\
25 \text { and } \\
26\end{array}$ \\
\hline 7. & $\begin{array}{l}\text { Kelurahan } \\
\text { Siring } \\
\text { Agung }\end{array}$ & 3 & $\begin{array}{l}\text { RT 09, } \\
07 \text { and } \\
02\end{array}$ \\
\hline 8. & $\begin{array}{l}\text { Kelang } \\
\text { Kelang }\end{array}$ & 3 & $\begin{array}{l}\text { RT } 70, \\
67 \text { and } \\
22\end{array}$ \\
\hline 9. & $\begin{array}{l}\text { Kelurahan } \\
\text { Ario } \\
\text { Kemuning }\end{array}$ & 1 & Resident \\
\hline 10. & $\begin{array}{l}\text { Kelurahan } \\
\text { Maskrebet }\end{array}$ & 1 & Resident \\
\hline 11. & $\begin{array}{l}\text { Kelurahan } \\
\text { Lawan } \\
\text { Kidul }\end{array}$ & 1 & Resident \\
\hline 12. & $\begin{array}{l}\text { Kelurahan } \\
9 \text { Ilir }\end{array}$ & 2 & Resident \\
\hline 13. & $\begin{array}{l}\text { Kecamatan } \\
\text { Ilir } 2\end{array}$ & 3 & $\begin{array}{l}\text { District } \\
\text { Officer }\end{array}$ \\
\hline & total & 24 & \\
\hline
\end{tabular}

\section{Findings and Discussion}

\section{Content Provider}

This model consists of the provision of static and dynamic content including product and news information. This content comes from an organization and may be tailored to meet customer needs. This model helps the task of service to the community. The characteristics of this model include: providing information about their own organizations, products, and services and focusing on the core business of the organization. Based on the observation, question and answer and interviews with some participants to the RT heads and some staff members of RT management related to the development of this model obtained data as follows.

The participants state that services that can be given by RT to community in the form of information about establishing youth organization such as the Young Muslim Activists. In addition, the heads and secretaries of the RT added that:
"For information on the establishment of organization can be seen at the kelurahan office or a duplicate of the form to establish a new organization, which can be taken in RT head home, but sometimes $R T$ only has the document of rules and procedures that are often asked ... ".

Furthermore, the RT's engagement is stated that every document issued by RT must be verified and approved by the RT head, and also approved by the all the units in the kelurahan. The information submitted by the participants is information on social and health activities, namely: "As a RT head, we need to spread the social activity schedule including gotong royong, poskamling, posyandu, posyandu activities for elderly, a mass circumcision, a public healthcare and drug addiction counseling etc, this information should always be delivered to every one of our citizens ..."

The head of RT further said that the delivery of activity information has been done through door to door, official invitation, or bulletin board which is placed in kamling post or via microphone in mosque or mushola. The RT secretary also emphasize that information technology is also used in the dissemination of information, for example the use of a conversation application. For example, Information can be distributed through WhatsApp group to all residents who have been included in the group.

Other information is also conveyed about information that is often requested by citizen to $\mathrm{RT}$ heads. The participant confirms that: "I am often asked by citizens about how the procedures for administration of documents such as identity cards (KTP-el), family cards, birth certificates and death certificates". Other documents were also requested by residents to the head of the RT, such as: letter of introduction for temporary residence, letter of introduction for An affidavit of single status, certificate of police records, poor mark certificate (SKTM), certificate of good conduct, certificate of ownership (goods, assets or other important letters in kelurahan area that can be used as credit guarantees in accordance with applicable rules), identity certificate, business domicile certificate, recommendation letter of marriage certificate, certificate of loss, etc. These questions are asked by citizens at meetings and discussion forum, or residents who come directly to RT head home, or through short message mobile phone and direct calls to RT head.

Other information is asked by the resident are licensing issues such as road closing permits, building permits (IMB) and business license certificates. Furthermore, the issues of legal services for the poor people such as making a lawsuit for the illiterate, the direction of the 
licensing procedures of prodeo, the refinement of power of attorney, the improvement of the lawsuit letter, the explanation of legal evidence, the explanation of how to file a rebuttal and answer and legal aid, information for inexpensive staple food, health counselling, and disaster response counselling.

From the information obtained above, it can be concluded that the head of RTs as the spearhead of government services might bridge the government and citizen. However, the information needed by the people can not be given by the RT head directly. Along with the advancement and use of information technology, there is a need to build e-government RT to help RT head to present much information as static content that can present correctly and quickly. The use of the WhatsApp group shows the readiness of citizens to use the data, which is a positive value as citizens' readiness to implement e-government at the RT / RW level.

Proposition 1: E-Government Rukun Tetangga with a complete content provider service makes one stop solutions in providing legal information services to the public.

\section{Direct-to-Citizen}

This model concerns with the terms of services directly to the customers and businesses including pages and subscription options that made specially. The characteristic of this model is focus on the transactions making and sales services provided by the organization itself. Users help themselves by focusing on self-service options. Based on the author's observation and interview result with the participant, the head of RT, the service which is given by the RT to the resident and community is in the form of donations to ease the burden of the family which is being affected by the adversity such as illness, accident, death, and so on. The participants state about the rules of social services for the society adversity with the requirement of affected family members should be domiciled in neighbourhood (RT) area, as described below:

"To obtain such a service, our society are required to fill in the membership forms and pay membership fees, for Muslims whose family died, procurement of bodies like a shroud, cotton, soap, rose water, spices, concave boards, and tombstones, already included in the value of compensation while for non-Muslim members, the corpse management will then be coordinated with religion leaders concerned".

In addition, participants also stated to provide direct services to the society that will make documents with the requirements such as filling the letter of introduction from RT / RW, attach a copy of the family card (KK), fill in the form, attach the original ID card for the extension and others for the procedures of new document creation services such as the creation of cover letters for making the electronic identity cards (KTP-el), family cards, birth certificates, introductory letter of public health insurance, death certificate, certificate of moving in and out / immigration, certificate of good conduct, certificate of ownership (goods, assets or other important letters in kelurahan area that can be used as credit collateral according to the prevailing rules), certificate of identity difference, certificate of domicile, business domicile certificate, recommendation letter of marriage certificate, letter of loss, licensing service such as introduction of road closing permit letter, crowds permit letter, building permit letter (IMB), recommendation letter of business license of online law aid services for the less fortunate people such as making letters of introduction to illiterates, guidance on the procedures of prodeo permits, power of attorney improvement, the improvement of the lawsuit, the explanation of legal evidence, the explanation of how to file a rebuttal and answer and the assistance of legal aid efforts and so forth. From this information is obtained that the RT service is a direct service of government to resident and society, it can be interpreted that the services of government to citizen in e-government order can be applied to those matters.

Proposition 2: Provision of direct services to the community in E-Government of Rukun Tetangga can empowering all levels of society through automatic response to online submissions.

\section{Value-Net-Integrations}

The concept of value-net-integrations is to coordinate the collection, processing, and distribution of information from several organizations, agencies or units in government. Its function is to coordinate the provision of services from other organizations and it does not provide services directly. Based on the observations and interviews with some participants, the head of RT and officials of the kelurahan offices related to the activity of coordinating the provision of services from other organizations is in the form of coordination of documents completeness administrative services with the relevant institutions such as the Health Office of Palembang to provide integrated service post including public health or Posyandu services for all people with toddlers, and family planning services (KB) for all family in need. Social Department, district (kecamatan) and kelurahan offices coordinate with 
the heads of RT to deliver social assistance such as rice for the poor and assistance in case of natural disasters and fires in the RT environment. The local police agency (Polda) or the resort police of Palembang city (Polres) and the National Narcotics Agency (BNN) coordinate with the head of the RT to conduct counselling about the dangers of drugs and ask for an active role of the society in maintaining environmental security by providing guard posts at each RT / RW. The Regional Revenue Department and the banking institution for the coordination of the distribution of land tax bill for each citizen and coordinate for that tax payment. Other forms of coordination are licensing procedures with government agencies such as coordination and procedures for making a building permit letter (IMB), building permit letter service (IMB) and coordinating the creation of a business license letter. Coordination of legal services for disadvantaged communities such as making lawsuits for illiterates, guidance on the procedure of the prodeo permit, lawsuit remedies, explanation of valid evidence, explanations on how to file a rebuttal and answer, legal aid assistance. Coordination of social infrastructure assistance and provision by the government such as the coordination of cheap basic needs for poor people, coordination of the provision and construction of worship places, coordination of the construction and improvement of streets and alleys, coordination of public toilets, coordination of clean water facilities, coordination of roadside ditch construction, coordination of garbage bins provision, coordination of street lighting installations, Coordination of education service assistance by department of education, such as the program of one RW one PAUD and illiteracy education service. Coordination of counselling implementation services by relevant agencies, such as Smart Voters Services. Other participants state that this coordination was carried out by submitting a request letter of activity, submitting a proposal for assistance and receiving village grants with relevant government agencies.

Proposition 3: E-Government of Rukun Tetangga as a coordination system and gather all the Government Units of Palembang to provide direct services to the community.

\section{Full-Service Provider}

This model concerns with the provision of facilitating an interaction between the government and the community through the direct information and service provision. Based on the author's observation and from the interview result with the head of RT and some society related to the provision of facilities needed by the society is the provision of security services / CCTV for Security. One of the resident states that the development of CCTV in the RT / RW environment is expected to monitor the areas and critical points of robbery crime and theft, with the existence of this monitoring system, it is expected that the situation at that point of vulnerability can be monitored directly so that follow-up treatment can be done quickly and accurately, the society said. The next service is the provision of smart community libraries, as we have already known: "... The development of science that cannot be prevented, therefore the application of the libraries for the community to be smart is very important for society so that every society does not miss information about the development of the era..., and citizens are expected to utilize this facility as well as possible in order to achieve prosperity together ".

Furthermore, the government can facilitate appropriate technology services so that every citizen can enjoy it for free, such as free internet development in RT / RW, where this assistance is intended for citizens who want to access egovernment. Another government service that is expected by the community is the provision of information and garbage disposal for each RT / RW so that people do not litter.

Proposition 4: E-Government Rukun Tetangga is an appropriate technology services that facilitates the community in accessing e-government provided by Palembang Government.

\section{Infrastructure Service Provider}

This model provides infrastructure services to support website development. Often infrastructure providers are established when many organizations find that they are in a state of developing a similar set of functions and they decided to concentrate the development and provision of services in one organization. In this case, functions can be developed once and provided to many users utilizing the benefits in economic scale. The characteristic of this model is to concentrate and shares services within an organization (semiautonomous) and provides these services to many public organizations that act as the user.

Based on the observations and interviews with the chairman and the community related to the provision of service facilities needed by citizens to access the government system is that citizens are constrained by the available infrastructure and cost issues. Therefore, it would be nice if citizens are given free internet facilities or "Internet for the people" by making internet surrounding points (hotspot) in certain locations, which can be accessed by residents especially the poor of RT / 
RW freely so that society can get information. Participant said that: "After free internet facility is very much needed by citizens to be able to access information moreover we have heard RT / RW net ... other steps can be made by providing public kiosk provided by a combination of government agencies and private or state-owned enterprises (BUMN) so citizens can interact with the local government and central by online."

The provision of internet infrastructure in South Sumatera has actually been presented with the "Sumsel FreeWifi" initiated by the Provincial Government of South Sumatera, but this program has been inactive at this time. As the information submitted by participants as follows:

"There used to be free internet in this Palembang area, but only in the certain places, but that was in the past, around 3 or 4 years ago, ... the benefits gained at that time are it was used only for Facebook and YouTube, Sir"

From the information obtained from the participants can be seen that the need of information technology infrastructure at RT / RW level is currently very much needed, especially when access to information services such as kiosk or self-service that can be reached by the bottom of society prepared for free.

Proposition 5: E-Government of Rukun Tetangga is obliged to provide supporting facilities for poor people to access e-government of Palembang Government.

\section{Collaboration}

This collaborative e-government concept facilitates the community to participate in providing ideas, suggestions or critiques in decision-making and policy. Based on the questions asked by the researcher and from the interviews with the head of RT and some staff members of RT related to the participation of citizens in providing ideas, suggestions or criticisms in determining and making decisions and policies in RT neighbourhood and local government. Participants said that there are unscheduled meetings or regular scheduled meetings every quarter to discuss about the environment (such as security, environmental hygiene, social activity, religious and educational). From the results of this meeting there are many inserts, ideas, suggestions, criticism submitted by the citizens that sometimes cannot be decided at the meeting because of limited meeting time at night. Suggestion of several of the people of the meeting and discussion at the meeting can be continued electronically through the online community such as chatting application and online discussion through WhatsApp, can share document to compare and evaluate the alternative policies that have been decided at the meeting so that societies will know the decision of the meeting. Furthermore, citizen participation is actively involved in counselling and meetings with government agencies. One of them is Smart Voters Service counselling (Warga Pemilih Cerdas) by KPU ahead of democracy party, health counselling and others.

Proposition 6: E-Government Rukun Tetangga is developed with ability to respond all suggestions, ideas and feedback in making policy in neighbourhood of $R T$.

\section{Virtual Communities}

This model is described as a model that involves creating a community or a group of repeat customers. This virtual community has an interesting topic and able to retain its users,

Based on the observations and interviews with the head of the RT who is at his home obtained information and data as follows:

"There are already forms of communities for dialogue / discussing and sharing the knowledge that our citizens and the RTs have done here or with other agencies. This community joins in WhatsApp and Millis groups. One of them is a community named "LSM-RT063" which stands for Layanan Sosial Masyarakat or social services for people who have sickness, accident, death, natural disaster, compensation to the poor, infak and sodakoh and others. The most important thing is the head of RT can spread immediately the important messages to all the community and the community will get the alert for each important message.

One of the other RT officials states that this community provides an opportunity for society of RT-RW and philanthropists to participate in social service programs, such as 1). provide grant funds to increase the cash strength of LSM-RT-RW, 2). provide direct benefits to the family of grief.

Another form of community that already exists is the community of providing online information services in the form of documentation and information of population data and regional development reports, where this community is only for head of the RT until the members just used the chat applications but now has moved to the WhatsApp application. Furthermore, there is a community named "Forum RT". It is an online discussion forum and information, one of the contents of the study is the procedure of handling and mass treatment for drug addicts / the mass treatment for drug addicts which cooperate with one member of BNN in implementing service program in that forum, hopefully with this service, 
society can be free from drugs.

Proposition 7: E-Government of Rukun Tetangga must have the ability of virtual community to facilitate communication among residents in neighbourhood of $R T$.

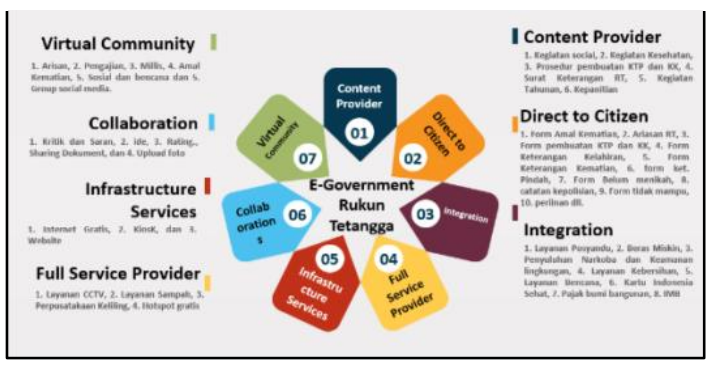

Figure 2. E-government Rukun Tetangga Model

\section{Conclusion and Future Research}

E-government is an electronic-based service provided by the government to facilitate and reach all levels of society. Although there are several studies investigating e-government services from variety of perspectives, today there is no academics or practitioners investigation which develops egovernment that can interact and communicate throughout all layers of society. One of the factors is that there are still many people who have difficulties in accessing e-government that exist today. This is because people do not have the ability to purchase equipment that is used to access e-government such as smartphones, laptops, computers and internet access [12]. To address this gap, this study adopted an e-government model developed by Marijn Janssen et al. / Government Information Quarterly 25 (2008) to understand how to develop e-government of RT to reach all levels of society. Based on interviews with the RT head, RT secretary, society and some district office staff, this study describes how to develop that egovernment of RT.

In terms of developing the RT e-government service, this study identifies seven of the eight dimensions developed by Maijin Janssen et al (2008), such as content providers, direct-to-citizen, net-value-integrations, full-service providers, infrastructure service providers, collaboration and virtual communities. Although these types of services are interrelated and one development will lead to another development, the study identifies a one service, direct-to-customer service that can implemented by the government to develop every dimension of e-government service capability.

Arguably, research has provided evidence that confirms that the types of services on the direct-tocustomer which is the foundation or stage for people to interact, in almost all existing government agencies.

In terms of factors influencing the identification of e-government services in Rukun Tetangga (RT), this study highlights the importance of social integration mechanisms in the community which always ask for help to the head of RT in any activities whether or not related to the government, for example, the making of ID cards and family card and the process of peace disputes until the loss of goods. The RT head is elected by the society so that resident is very high confidence to RT head. It can be seen from the culture of the community and society who always delegate their government-related affairs to the head of RT.

The finding of this study also reveals the role of RT head as a coordination between the community and outsiders is very important. So, in this study reveals that every government agency in providing services directly to the community is always associated with the head of the RT, for example Integrated Service Post (Posyandu) and Family Planning (KB) services from the Department of Health, natural disasters and fire Service from the Department of Social and others. In closing, it is important to acknowledge some limitations in this study and suggest possible paths for further research. First, the ability to generalize from the results of this study is limited by the small number of cases and interviews conducted. Secondly, this research only focuses on the development of Rukun Tetangga (RT) eGovernment and future research should investigate a broader range of issues including the deployment of service points (network service point) and the development of Rukun Tetangga e-Government prototype. Thirdly, the current research has provided the viewpoints of both RT, community and sub-district offices, future research might investigate the extent to which e-Government Rukun Tetangga can help the government of Palembang city in providing excellent service. Fourth, arguably research has identified seven dimensions based on the e-government model developed by Marijn Janssen et al (200). Future research may be able to combine between the IT infrastructure point of view and user behaviors. While acknowledging this limitation, this study still provides a model of RT e-government and a series of propositions that accompany it, that will provide a useful foundation for future research. 


\section{References}

[1] D. Antoni, Apriliani, I. H. M, and A. Muhamad, "Critical Factors of Transparency and Trust for Evaluating Egovernment Services for the Poor," in 2 th International Conference on Informatics and Computing, Jayapura, Papua, 2017.

[2] D. Aldrich, J. C. Bertot, and C. R. McClure, "E-government: Initiatives, developments, and issues," Government information quarterly, vol. 19, pp. 349355, 2002.

[3] E. Rahardjo, D. Mirchandani, and K. Joshi, "E-government functionality and website features: A case study of Indonesia," Journal of Global Information Technology Management, vol. 10, pp. 31-50, 2007.

[4] R. Heeks and S. Bailur, "Analyzing egovernment research: Perspectives, philosophies, theories, methods, and practice," Government Information Quarterly, vol. 24, pp. 243-265, 4// 2007.

[5] W. Kumorotomo, "Kegagalan Penerapan E-Government dan Kegiatan Tidak Produktif dengan Internet," ed, 2009.

[6] D. A. Mirchandani, J. H. Johnson Jr, and K. Joshi, "Perspectives of citizens towards e-government in Thailand and Indonesia: A multigroup analysis," Information Systems Frontiers, vol. 10, pp. 483-497, 2008.

[7] B. Furuholt and F. Wahid, "EGovernment Challenges and the Role of Political Leadership in Indonesia: The Case of Sragen," in Hawaii International Conference on System Sciences, Proceedings of the 41st Annual, 2008, pp. 411-411.

[8] M. Janssen, G. Kuk, and R. W. Wagenaar, "A survey of Web-based business models for e-government in the Netherlands," Government Information Quarterly, vol. 25, pp. 202-220, 4// 2008.

[9] F. Kurniawan, N. A. Rakhmawati, A. N. Abadi, M. Zuhri, and W. T. Sugiyanto, "Indonesia local government information completeness on the web," Procedia Computer Science, vol. 124, pp. 21-28, 2017/01/01/ 2017.

[10] R. K. Verma, S. Kumar, and P. V. Ilavarasan, "Government portals, social media platforms and citizen engagement in India: Some insights," Procedia Computer Science, vol. 122, pp. 842-849, 2017/01/01/ 2017.
[11] K. Layne and J. Lee, "Developing fully functional E-government: A four stage model," Government Information Quarterly, vol. 18, pp. 122-136, //Summer 2001.

[12] D. Antoni, Apriliani, M. I. Herdiansyah, and M. Akbar, "Critical factors of transparency and trust for evaluating egovernment services for the poor," in 2017 Second International Conference on Informatics and Computing (ICIC), 2017, pp. 1-6.

[13] R. Zambrano, "E-governance and development: Service delivery to empower the poor [J]," Social and Organizational Developments through Emerging E-Government Applications: New Principles and Concepts: New Principles and Concepts, vol. 98, 2009.

[14] J. W. Creswell, Research Design: Qualitative, Quantitative, and Mixed Methods Approaches. Los Angeles: SAGE Publications, 2009.

[15] R. K. Yin, Case study research: Design and methods vol. 5: Sage Publications, Inc, 2009.

[16] W. L. Neuman, Social research methods: Qualitative and quantitative approaches: Pearson Education, 2013. 